\title{
Analysis of rock mass and anchor support elements deformations during the long-term maintenance of mine workings
}

\author{
Sergey Tsibaev $^{1}$, Alexey Renev ${ }^{1}$, Rinat Zainulin ${ }^{1}$, and Alexander Kucherenko ${ }^{2}$ \\ ${ }^{1}$ T. F. Gorbachev Kuzbass State Technical University, Russia, 650000, Kemerovo \\ ${ }^{2}$ JSC SUEK-Kuzbass, Russia, 652507, Leninsk-Kuznetsky
}

\begin{abstract}
The results of instrumental and visual assessment of near-rock massif and anchor support elements state in the conditions of long-term maintenance of mine workings has been presented. Particular attention is paid to underground mines in a flooded state. The result of various profiles fixing bolts strength tests of in the roof and sides of the workings has been presented. It has been established that the probability distribution of the anchoring bolts force in the holes in roof of the workings obeys the normal distribution tendency. The result of a radar survey of roof rocks using the Georadar OKO-2 has been analyzed. It was revealed that the height of the stratification of rocks in the mine workings roof varies from $0.2 \mathrm{~m}$ to 2.25 $\mathrm{m}$, a comparison is made with the theoretical height of the collapse arch. The propensity of the near rock massif to water saturation has been estimated, the height of the water saturation of the roof rocks has been established. It has been established that the height of moisture depends on the arch of rock stability formed during the survey period. It has been found that water saturation of the rocks leads to a decrease in the specific cohesion of the resin capsules bonding composition with the walls of the hole by $55-67 \%$ in roof and by $72 \%$ in walls of mine workings.
\end{abstract}

\section{Introduction}

The tragedy that occurred in May 2010 at the Raspadskaya mine caused to enormous human casualties and dramatic damage to the capital funds of the mine itself. As a result of the impact of the blast wave, high temperature and flooding, the support of a significant part of the underground mine workings of the mine was broken. It should be noted that work to eliminate the consequences of the accident at the mine is ongoing. Thus, the primary goal of the study is to assess the effect of the blast wave and flooding on the state of anchoring of mine workings. The object of the study was underground mine workings of Raspadskaya coal mine, exposed to blast, heat and flooding. The planned volume of the study included workings carried out in the coal seams: 3-3a, 7-7a, 9, 10.The total length of the surveyed mine workings was about $60 \mathrm{~km}$.

Of the total number of surveyed workings, 39 mine workings were flooded. The period of stay of the workings in the flooded state was different, varying from 6 months to 30 months (Fig. 1). The total length of the flooded workings was 20195 m. [1] (Fig. 2). 


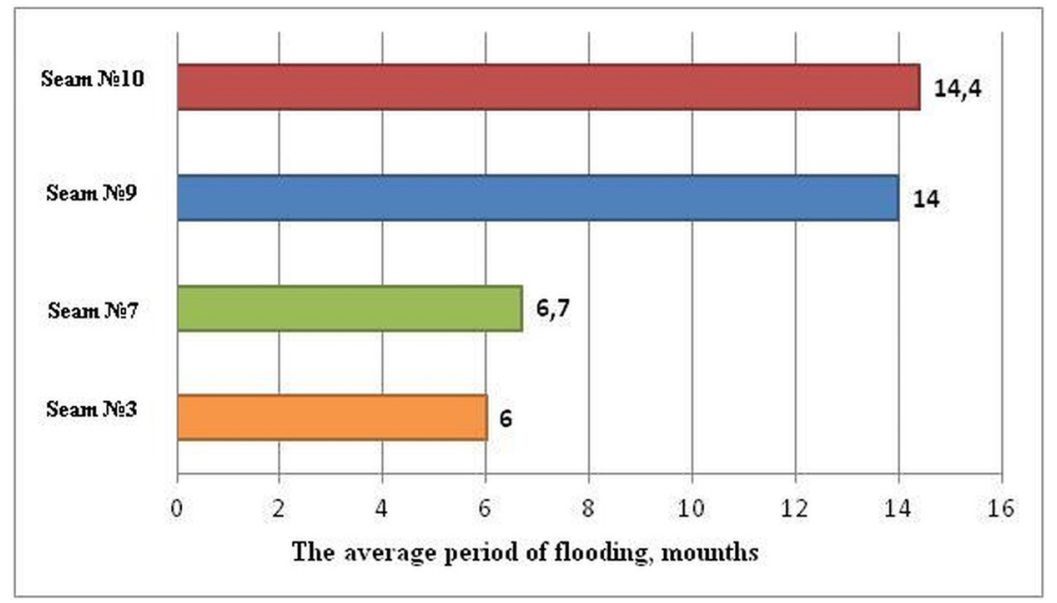

Fig. 1. Distribution of the average flooding period of underground mine workings "Raspadskaya" mine by coal seam, months.

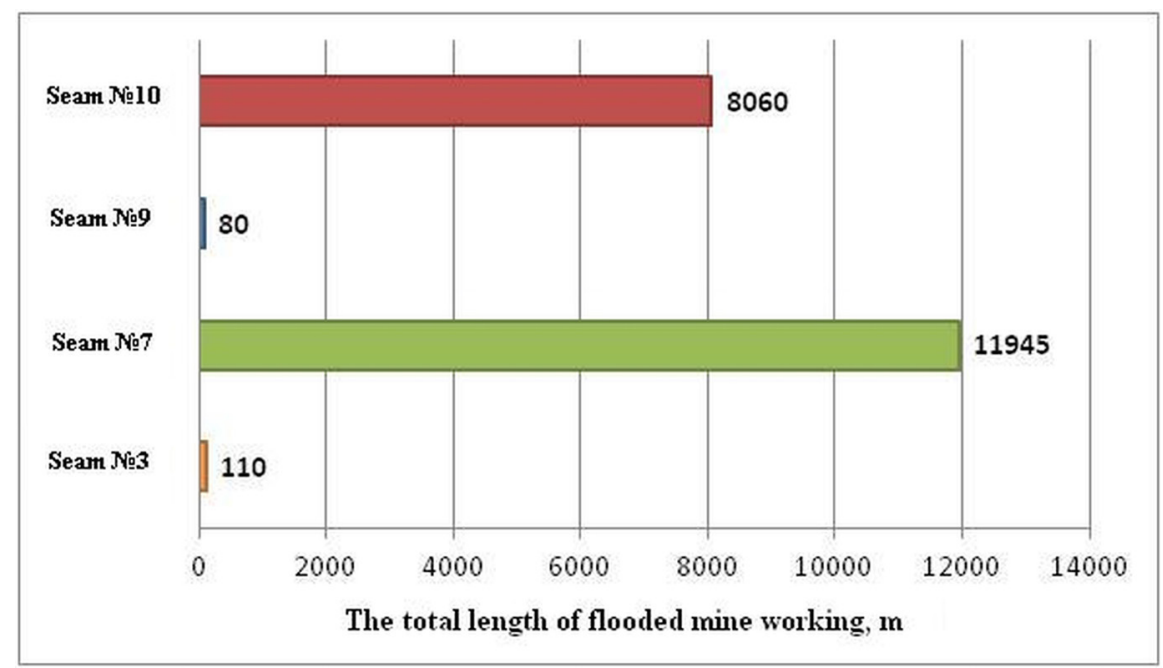

Fig. 2. The distribution of flooded mine workings length of the "Raspadskaya" mine by coal seam, m.

\section{The results}

A survey of the workings was carried out according to the established methodology [1], an act of commission inspection was prepared for each surveyed working. The actual state of the workings was sketched, evaluated by measurements. The elements of the anchor support were inspected visually, the tightening of the nuts was checked with a wrench or a torque wrench KDM-5. Anchors were loaded with a PKA-3 or PKA-1 rod-extractor. The mine working dimaentions were measured by VNIMI tape measure, as well as by modern measuring tape measures $[2,3]$.

Evaluation of the impact of mine workings flooding on the condition of mine workings and anchor support was carried out by loading the anchors with a rod-extractor and assessing the actual values of the specific cohesion of the fastener with walls of the hole and with bolts by the loading force. The state of the array was estimated by the specific 
cohesion of the bonding composition with borehole walls, and the actual cohesive properties of the bonding composition were evaluated by the specific cohesion of the bonding composition with bolts. In addition, a survey was conducted of the workings by the radar method using the OKO-2 Georadar [2].

The anchoring force of the bolts were evaluated using the PKA-3 device, according to the results of loading the anchors in the roof and walls of the workings in coal seams 9,10 , $7-7 \mathrm{a}, 3$, statistical series has been compiled. According to the data of statistical series, the probability distribution curves of the loading forces of the anchors has been drawed (Fig. 3, Fig. 4, Fig. 5). It has been established that the probability distribution of the anchoring force of anchors in the holes in the roof and wallsof the workings obeys the distribution law:

$$
P_{\mathrm{i}}=\frac{1}{\delta_{\mathrm{x}} \cdot 2 \pi} \cdot e^{-\frac{\left(x_{\mathrm{i}}-m_{\mathrm{x}}\right)^{2}}{2 \sigma_{\mathrm{x}}^{2}}}
$$

where: $\sigma_{\mathrm{x}}-$ the standard deviation of loading; $x_{\mathrm{i}}-$ the loading force; $m_{\mathrm{x}}-$ the mathematical expectation (average value).

The mathematical expectation (average value) $m_{\mathrm{x}}=97,05 \mathrm{\kappa}$;

The dispersion $D_{\mathrm{x}}=68,1 \mathrm{\kappa H}^{2}$;

The standard deviation of loading $\sigma_{\mathrm{x}}=8,25 \mathrm{\kappa H}$.

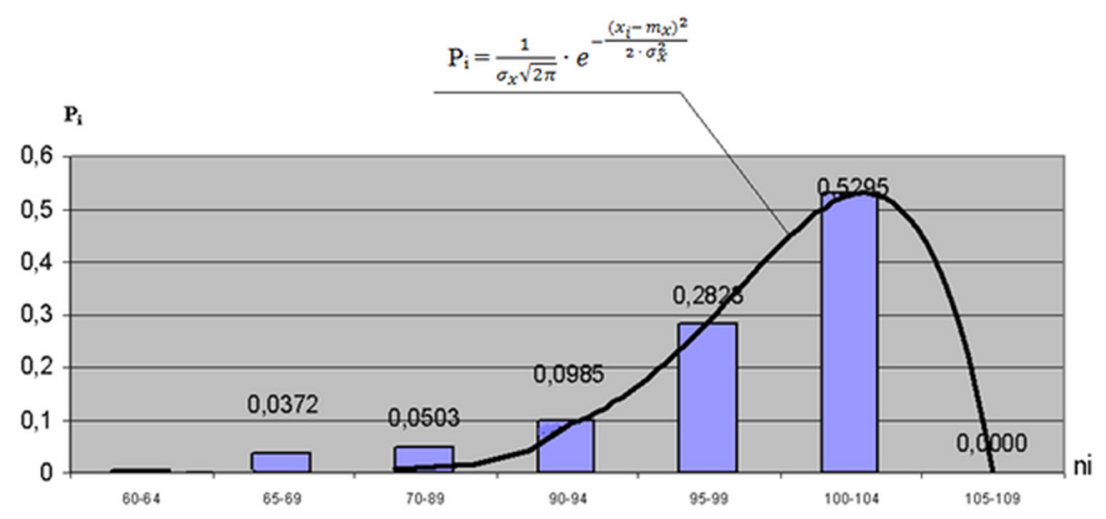

Fig. 3. The probability distribution curve of the loading force of screw profile bolts.

The distribution curve of the fixing forces in the holes of the roof of the anchors from a round steel profile is shown in Fig. 4. The mathematical expectation (average value) $m_{\mathrm{x}}$ is $72,75 \mathrm{\kappa H}$, the standard deviation of loading $\sigma_{\mathrm{x}}$ is $7,69 \mathrm{\kappa H}$.

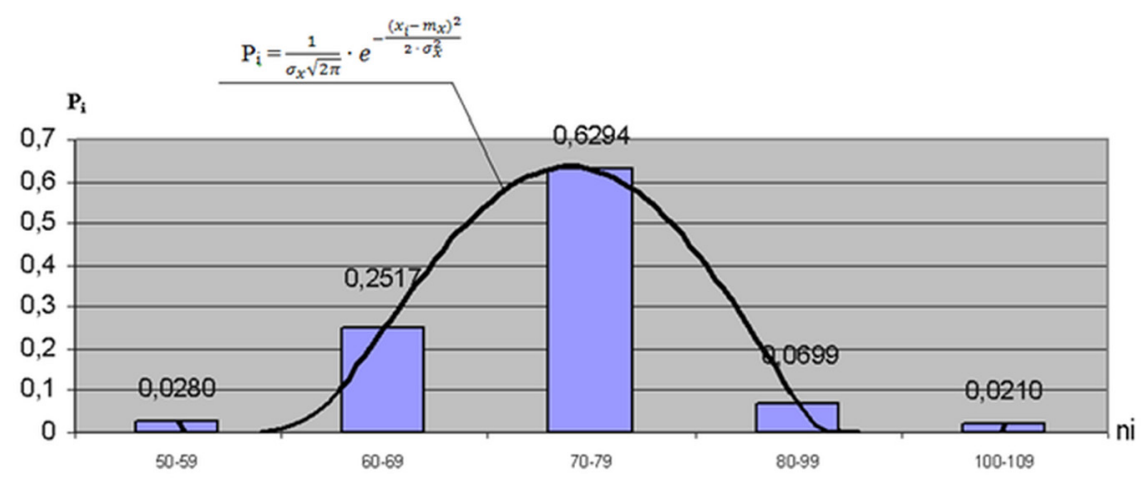

Fig. 4. The probability distribution curve of the loading force of round profile bolts. 
The walls of the workings are supported with steel-polymer anchors such as AVR-16, AVR-20, ASP-20, as well as expansion anchors SHK-1M. In fig. Figure 5 shows the distribution curve of the probability of the effort of fixing the anchor rods in the walls of the workings. On the walls of the workings, the fixing force of steel-polymer anchors is:

The mathematical expectation (average value) $m_{\mathrm{x}}=45,38 \mathrm{\kappa H}$;

The dispersion $D_{\mathrm{x}}=89,1 \kappa \mathrm{H}^{2}$;

The standard deviation of loading $\sigma_{\mathrm{x}}=9,44 \mathrm{\kappa} H$.

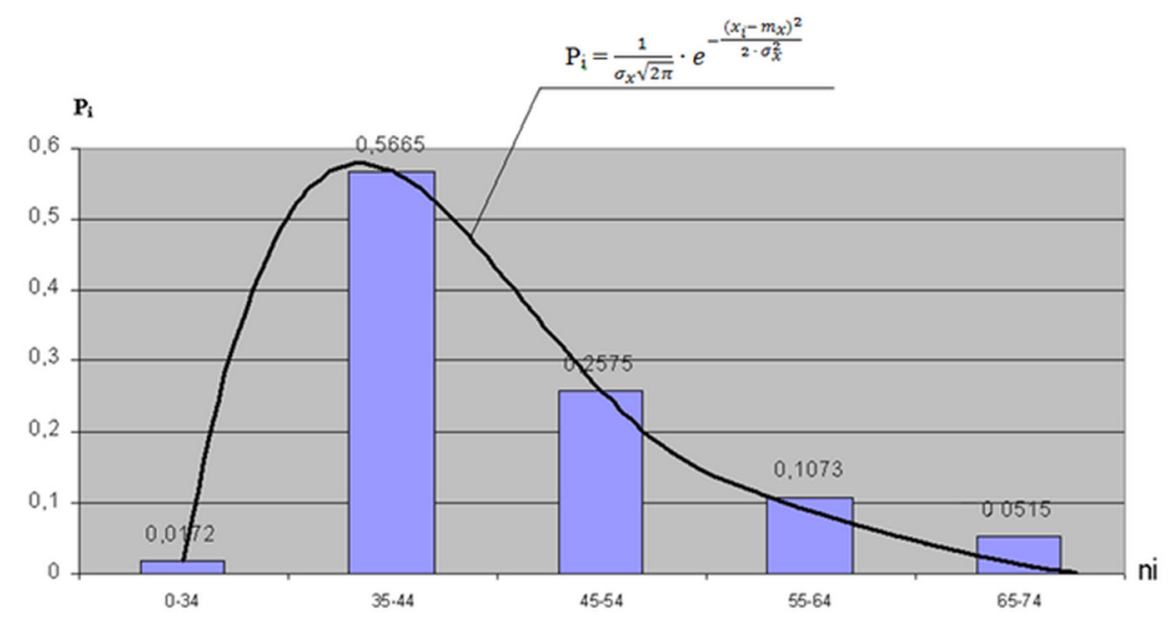

Fig. 5. The probability distribution curve of the loading force of steel-polymer anchors in the holes of the lateral workings.

To determine the height of water saturation and the actual deformations of the near roof layers additional radar studies were carried out. The most complete radar method was an examination of the workings of formation 9 in block No. 4 [2]. The survey results of the conveyor incline 4-9, located in the flood zone, are given below.

The principle of operation of a georadar is based on the emission of ultra-wideband nanosecond pulses, the reception of signals reflected from media interfaces, the processing of received signals, followed by the measurement of time intervals by reflected pulses. The base principles of georadar survey relate to o the classical principles of radar survey $[4,5]$.

Georadar studies were performed using a parallel profile system. The length of single profiles was up to 100 meters. The distance between the profiles was taken up to $10 \mathrm{~cm}$. The results of the survey of the condition of the rocks in the roof show the following:

Over the entire length of the incline, the lower layers of the roof rocks detached from the main massif, the height of the peeled and collapsed rocks varies from $0.1 \mathrm{~m}$ to $0.6 \mathrm{~m}$, an average of $0.3 \mathrm{~m}$. [4]. The height of the stratification of rocks is variable, in some areas of the rock of the immediate roof it is stratified to a height of 1.2-1.5 m. In a significant part of the areas, the rocks are moistened (Fig. 6) [4].

In moistened rocks areas, detachment of rocks and their collapse are sometimes observed, and the physical-mechanical properties of the rocks in these areas are reduced. Thus, water saturation of rocks leads to a decrease in the strength properties of rocks. The resistance of rocks to compression, stretching is reduced. Elastic properties are reduced, as well as adhesion and the angle of internal friction of the rocks [6]. 


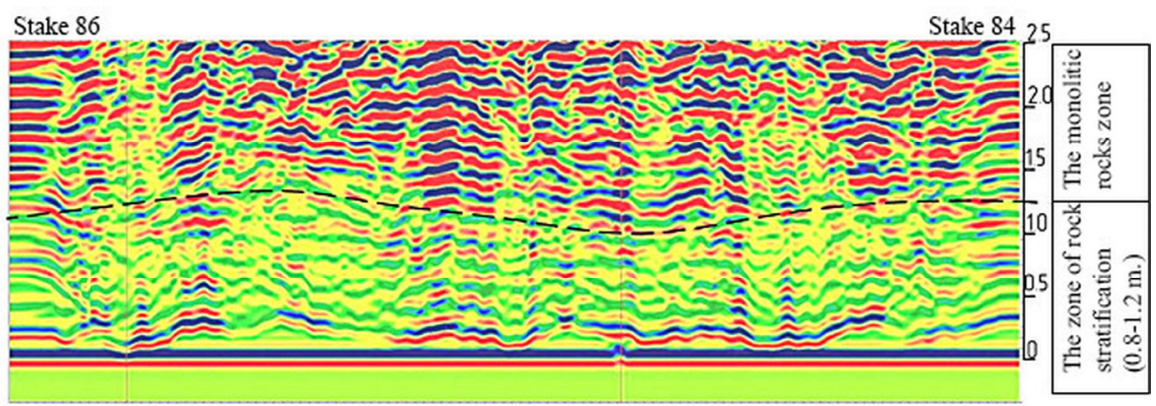

Fig. 6. The radargram of roof rocks at conveyor incline 4-9 (stake 86-84 area).

Water saturation is determined by many factors, the main ones being: moisture capacity, which is determined by the natural porosity of the rocks. Moistening of rocks during flooding is accompanied by decompression expansion of the rocks in connection with their softening. The rocks increase in volume (swell), and cracks are closed, the rock mass becomes more monolithic, but less durable and stable [7].

Natural fracturing affects the water saturation of rocks [8,9]. With an increase in fracturing, the moisture saturation of rocks increases. The permeability of rocks has a significant effect, characterized by a permeability coefficient or a filtration coefficient. Hydrogeological characteristics of the rocks are given in tables 1 and 2. Assessment of the hydrogeological properties of the rocks of the Raspadskoye deposit shows that the bedrocks are prone to water saturation.

Table 1. Physical-mechanical properties of bedrocks.

\begin{tabular}{|l|c|c|c|c|c|}
\hline \multicolumn{1}{|c|}{$\begin{array}{c}\text { The } \\
\text { properties }\end{array}$} & Sandstone & $\begin{array}{c}\text { Sandstone and } \\
\text { aleurolite } \\
\text { overlaytion }\end{array}$ & Aleurolite & Clay stone & $\begin{array}{l}\text { Conglomera } \\
\text { tes }\end{array}$ \\
\hline $\begin{array}{l}\text { Protodiyakono } \\
\text { v hardness }\end{array}$ & $\frac{7 \div 16}{10.6}$ & $\frac{5 \div 14}{7.3}$ & $\frac{1.5 \div 12.0}{6.7}$ & $\frac{3 \div 5}{4}$ & $\frac{7 \div 8}{7.5}$ \\
\hline $\begin{array}{l}\text { Total rock } \\
\text { openness, \% }\end{array}$ & $\frac{1.21 \div 7.1}{3.78}$ & $\frac{0.97 \div 6.45}{3.26}$ & $\frac{0.19 \div 8.11}{4.68}$ & $\frac{2.33 \div 5.71}{4.02}$ & $\frac{3.48 \div 4.26}{3.87}$ \\
\hline $\begin{array}{l}\text { Natural } \\
\text { moisture } \\
\text { content, \% }\end{array}$ & $\frac{0.58 \div 2.64}{1.50}$ & $\frac{0.91 \div 3.47}{1.93}$ & $\frac{1.14 \div 3.47}{2.13}$ & $\frac{2.76 \div 3.02}{2.89}$ & $\frac{0.99 \div 1.06}{1.02}$ \\
\hline $\begin{array}{l}\text { Water } \\
\text { absorption, \% }\end{array}$ & $\frac{0.34 \div 1.93}{1.15}$ & $\frac{0.67 \div 1.69}{1.19}$ & $\frac{0.35 \div 1.67}{1.03}$ & 2.11 & $\frac{0.9 \div 1.25}{1.07}$ \\
\hline
\end{tabular}

Table 2. Physical-mechanical properties of coal seams.

\begin{tabular}{|l|c|c|c|c|c|c|}
\hline \multicolumn{1}{|c|}{ The properties } & Seam 15 & Seam 11 & Seam 9 & $\begin{array}{c}\text { Seam 7- } \\
\text { 7a }\end{array}$ & $\begin{array}{c}\text { Seam 6- } \\
\text { 6a }\end{array}$ & $\begin{array}{c}\text { Seam 3- } \\
\text { 3a }\end{array}$ \\
\hline Signs of soaking & - & Yes & No & Yes & No & - \\
\hline Humidity, \% & 2.0 & - & 2.1 & 1.5 & 2.2 & - \\
\hline Specific gravity, g/cm ${ }^{3}$ & - & - & 1.46 & - & 2.35 & 2.57 \\
\hline Bulk density, \% & - & - & 1.32 & - & 2.06 & 2.42 \\
\hline Total rock openness, \% & - & - & 9.59 & - & 8.54 & 5.9 \\
\hline Water absorption, \% & 0 & 6.9 & 5.5 & 14.2 & 9.8 & - \\
\hline
\end{tabular}




\section{Discussion}

Using the mathematical expectation values it could be possible to determine the specific cohesion of the fastening structure of chemical ampoules with shot walls and bolts. The specific cohesion of the fastening structure of chemical ampoules with shot walls can be determined by this way:

$$
\tau_{\mathrm{m}}=\frac{m_{\mathrm{x}}}{\pi \cdot d_{\mathrm{II}} \cdot l_{3 . \mathrm{a}} \cdot K_{\mathrm{II}}}
$$

The specific cohesion of the fastening structure of chemical ampoules with bolts can be deter-mined by this way:

$$
\tau_{\mathrm{c}}=\frac{m_{\mathrm{x}}}{\pi \cdot d_{\mathrm{aH}} \cdot l_{3 . \mathrm{a}} \cdot K_{\mathrm{II}}}
$$

In the type: $\ell$ - the length of bolt fastening; $K$ - the coefficient of deteriorating conditions in the holes; $d_{\mathrm{h}}-$ the hole's diameter $\left(d_{\mathrm{h}}=30 \mathrm{~mm}\right) ; d_{\mathrm{b}}-$ the bolt's diameter $\left(d_{\mathrm{b}}=20 \mathrm{~mm}\right) ; ; m_{\mathrm{x}}$ - the mathematical expectation (average value), $\mathrm{kH}$.

The results of calculations performed by the formulas $(2,3)$ are given in table. 3 . Analyzing the calculation data, it is clear that water saturation leads to a decrease in the actual strength of bolts fixing in holes by $37 \%$ when fastened in sandstones and by $48 \%$ when fixed in siltstones. Despite a significant decrease in the actual strength of fasteners, their values don't exceed the breaking strength of bolts. The data obtained are confirmed by the fact that as a result of more than 900 single tests to verify the strength of anchoring the bolts in the boreholes, no episodes of displacements of more than $5 \mathrm{~mm}$ were revealed.

An analysis of the physical-mechanical properties of coals (table 3) establishes a significant difference between the coals of different seams. Some belong to the category of hydrophobic (seams 9,11 ), there are no signs of coal seams to soak. The coals of seas 3-3a, $7-7 \mathrm{a}, 9,10$ are prone to water saturation.

\begin{tabular}{|c|c|c|c|c|c|c|}
\hline $\begin{array}{c}\text { Fastening } \\
\text { surface }\end{array}$ & $\begin{array}{c}\text { Specific } \\
\text { cohesion } \\
\tau, \text { MPa }\end{array}$ & $\begin{array}{l}\text { Fastening } \\
\text { length } \ell, \\
\text { (m) }\end{array}$ & $\begin{array}{c}\text { The strength } \\
\text { of the } \\
\text { composition } \\
P, \text { кH }\end{array}$ & $\begin{array}{c}\text { Anchor } \\
\text { breaking } \\
\text { strength, } \\
\text { screw } \\
\text { profile } d= \\
20 \mathrm{~mm} \text {. } \\
N_{\mathrm{a}}, \mathbf{K H}\end{array}$ & $\begin{array}{c}\text { Anchor } \\
\text { breaking } \\
\text { strength, } \\
\text { round } \\
\text { profile } d= \\
20 \mathrm{~mm} . \\
N_{\mathrm{a}}, \mathbf{k H}\end{array}$ & $\begin{array}{c}\text { Anchor } \\
\text { breaking } \\
\text { strength, } \\
\text { screw } \\
\text { profile } d= \\
16 \mathrm{~mm} . \\
N_{\mathrm{a}}, \mathbf{k H}\end{array}$ \\
\hline $\begin{array}{l}\text { Dry } \\
\text { sandstone }\end{array}$ & 3.3 & 1.0 & 310 & \multirow{7}{*}{164} & \multirow{7}{*}{100} & \multirow{7}{*}{110} \\
\hline $\begin{array}{l}\text { Wet } \\
\text { sandstone } \\
(W=5 \%)\end{array}$ & 2.1 & 1.0 & 197 & & & \\
\hline Dry silstone & 4.0 & 1.0 & 376.8 & & & \\
\hline $\begin{array}{l}\text { Wet } \\
\text { silstone } \\
(W=8 \%)\end{array}$ & 2.1 & 1.0 & 197 & & & \\
\hline Coal & 2.7 & 1.0 & 254 & & & \\
\hline Coal & 2.7 & 0.5 & 127 & & & \\
\hline $\begin{array}{l}\text { Steel bolt } \\
d=20 \mathrm{~mm} .\end{array}$ & 8.9 & 1.0 & 558 & & & \\
\hline
\end{tabular}

Table 3. The values of the fastening force of the fastening composition with various surfaces. 


\begin{tabular}{|l|c|c|c|c|c|c|}
\hline & 8.9 & 0.5 & 279.5 & & & \\
\cline { 1 - 3 } $\begin{array}{l}\text { Steel bolt } \\
d=16 \mathrm{~mm} .\end{array}$ & 8.9 & 0.5 & 223.6 & & & \\
\hline
\end{tabular}

Investigations of near roof layers state have shown that the roof rocks in the conditions of Raspadskaya mine are prone to water saturation. Water saturation is determined by many factors, the main ones being: moisture capacity, which is determined by the natural porosity of the rocks. Natural fracturing has a significant effect on water saturation of rocks. With an increase in fracturing, water saturation of rocks increases. The permeability of rocks has a significant effect, characterized by a permeability coefficient or a filtration coefficient.

When surveying the conveyor incline 4-9 (Fig. 6) the wetting of the rocks was noted that the wetting height depends on the set of rock stability formed during the survey period. In the surveyed workings, the height of the intensely moistened layers varied from $0.2 \mathrm{~m}$ to $2.5 \mathrm{~m}$ (average value of $1.5 \mathrm{~m}$ ) and linearly depends on the actual width of the working:

$$
h_{c}=(0,2-0,25) B \text {, }
$$

In the type: $h_{\mathrm{c}}$ - the height of the saturated layers of the roof, $\mathrm{m} ; B$ - the mine working width, $\mathrm{m}$.

The surveys of coal seams 10, 9, 7-7a, 3-3a mine workings found that the height of the intensely moistened roof layers, obtained by means of a radar survey and the height of the collapse of rocks, calculated according to the theoretical foundations of the set of natural equilibrium have close results, which confirms the correctness of instrumental surveys.

The water saturation height obtained by the radar data varies from $0.2 \mathrm{~m}$ to $2.5 \mathrm{~m}$ (curve 2 ), the calculated theoretical height of the collapse arch in the workings varies from $0.15 \mathrm{~m}$ to $2.8 \mathrm{~m}$ (curve 1 in Fig. 7).

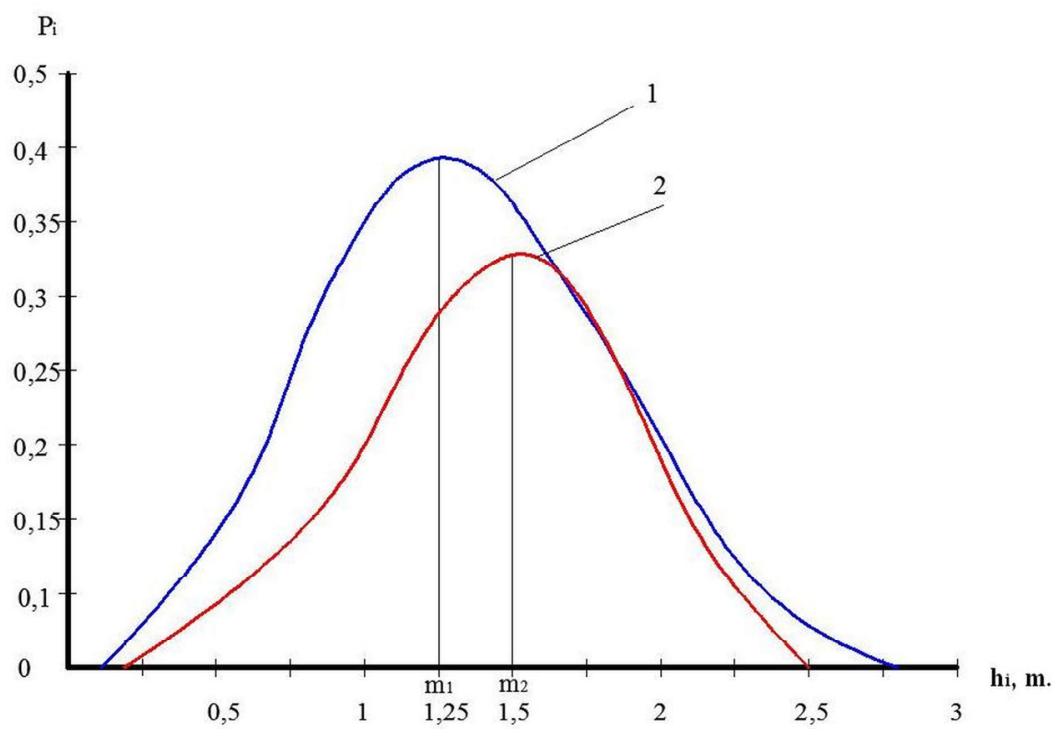

Fig. 7. The probability distribution of the height of the arch of destruction of the roof rocks in the workings: 1 - the probability curve of the height of the separation of rocks in the roof of the workings, calculated according to the theoretical foundations of the balance of equilibrium; 2 - probability curve of the height of the moistened layers in the roof of the workings, obtained using a radar survey. 


\section{Conclusions}

1. As a result of field studies in the conditions of Raspadskaya mine were surveyed over 57 $\mathrm{km}$. mine workings. More than $20 \mathrm{~km}$. of the total number were exposed to natural flooding for a period of 6 to 30 months. More than 900 unit tests of checking the bolts strength in holes has been made. Regardless of the fact of exposure to moisture, in none of the tests the displacement of the bolts relative to the holes did not exceed $5 \mathrm{~mm}$.

2. According to the results of tests of the bolts strength in holes, statistical series are constructed. Analytical studies have established that the influence of moisture causes a decrease in the specific cohesion of the bonding polymer composition with twalls of the hole by $37 \%$ when fixed in sandstones and by $48 \%$ when fixed in siltstone. However, the amount of fixing force in water-saturated rocks still exceeds the breaking force of the bolts. Therefore, the effect of moisture does not have a noticeable effect on the bearing capacity of the lining.

3.Geophysical studies using the radar method have established that intense water saturation of the rocks in the roof of the workings occurs within the limits of the formed balance of equilibrium. In the mine workings under study, the height of intensely moistened layers varied from $0.2 \mathrm{~m}$ to $2.5 \mathrm{~m}$ (average value $1.5 \mathrm{~m}$ ) and is in linear relation with the actual width of the workings

4. The decrease in the strength properties of rocks under the influence of moisture saturation must be taken into account when restoring and restructuring workings after pumping water and draining.

\section{References}

1. A. Renev, S. Tsibaev, S. Kalinin, Proceedings of the 9th China-Russia Symposium "Coal in the 21st Century: Mining, Intelligent Equipment and Environment Protection", 176, 361-366

2. S. Tsibaev, A. Renev, K. Evgenyi, D. Zaiatdinov, IVth International Innovative Mining Symposium, 105, 01027 (2019)

3. The survey procedure of mine workings conditions supported by bolts and about bolt work conditions after 5 years exploitation (Prokopevsk, KuzSTU, 2007)

4. A. Abramovich, E. Pudov, E. Kuzin, E3S Web Conf., 21, 01012 (2017)

5. Technical specifications and instruction manual for radio device for subsurface sounding (Georadar, Ramenskoe, 2009)

6. P. Colback, B. Wiid, Proceedings of the 3rd Canadian Rock Mechanism Symposium, 65-83 (1965)

7. Li D., Wong L. N. Y., Liu G., Zhang X. Engineering Geology, 126, 46-66 (2012)

8. C. Mark, New Technology for Coal Mine Roof Support, 2, 111-132 (2000)

9. Ogata Y., Jung W., Kubota S., Wada Y., Materials Science Forum, 465, 361-366 (2004)

10. S. S. Tsibaev, S. I. Kalinin, A. A. Renev, D. V. Zorkov, Mining Informational and Analytical Bulletin, Series Mining Engineer-Manager's Library, 5, 35- 43 (2015) 